IZA DP No. 4892

Immigrants at New Destinations:

How They Fare and Why

Anabela Carneiro

Natércia Fortuna

José Varejão

April 2010 


\title{
Immigrants at New Destinations: How They Fare and Why
}

\author{
Anabela Carneiro \\ University of Porto and CEF.UP \\ Natércia Fortuna \\ University of Porto and CEF.UP \\ José Varejão \\ University of Porto, CEF.UP \\ and IZA
}

Discussion Paper No. 4892

April 2010

IZA

P.O. Box 7240

53072 Bonn

Germany

Phone: +49-228-3894-0

Fax: +49-228-3894-180

E-mail: iza@iza.org

\begin{abstract}
Any opinions expressed here are those of the author(s) and not those of IZA. Research published in this series may include views on policy, but the institute itself takes no institutional policy positions.

The Institute for the Study of Labor (IZA) in Bonn is a local and virtual international research center and a place of communication between science, politics and business. IZA is an independent nonprofit organization supported by Deutsche Post Foundation. The center is associated with the University of Bonn and offers a stimulating research environment through its international network, workshops and conferences, data service, project support, research visits and doctoral program. IZA engages in (i) original and internationally competitive research in all fields of labor economics, (ii) development of policy concepts, and (iii) dissemination of research results and concepts to the interested public.
\end{abstract}

IZA Discussion Papers often represent preliminary work and are circulated to encourage discussion. Citation of such a paper should account for its provisional character. A revised version may be available directly from the author. 
IZA Discussion Paper No. 4892

April 2010

\begin{abstract}
Immigrants at New Destinations: How They Fare and Why*

Using matched employer-employee data, we identify the determinants of immigrants' earnings in the Portuguese labor market. Results previously reported for countries with a long tradition of hosting migrants are also valid in a new destination country. Two-thirds of the gap is attributable to match-specific and employer characteristics. Occupational downgrading and segregation into low-wage workplaces are two major causes behind the wage gap.
\end{abstract}

JEL Classification: J15, J24, J61

Keywords: immigrants' earnings, workplace concentration of immigrants, matched employer-employee data

Corresponding author:

José Varejão

Faculdade de Economia

Universidade do Porto

Rua Dr Roberto Frias

4200-464 Porto

Portugal

E-mail:varejao@fep.up.pt

\footnotetext{
* We would like to thank Alessandra Venturini, Barry Chiswick, Carmel Chiswick, Catalina AmuedoDorantes and Guillermina Jasso for comments on previous versions of the paper. Financial support from Fundação para a Ciência e a Tecnologia (Research grant no. PIQS/ECO/50044/2003) is deeply appreciated. We also thank the Gabinete de Estratégia e Planeamento do Ministério do Trabalho e da Solidariedade Social that kindly allowed us to use the data.

CEF.UP (Center for Economics and Finance at University of Porto) is supported by the Fundação para a Ciência e Tecnologia (FCT), Portugal.
} 


\section{Introduction}

In the very heart of today's immigration debate lies the question of how well immigrants fare at destination. The answer to this question crucially determines the social and economic consequences of immigration for receiving countries.

The comparison between successive cohorts of immigrants to the United States unequivocally demonstrated the importance of skills in the process of shaping the economic performance of immigrants both in the immediate post-migration period and over the long-run (see Borjas, 1999, e.g.). Yet, it is also well-know that human capital accumulated at home, through schooling or labor market experience, instantaneously looses value as individuals cross national borders. The magnitude of this loss is significantly influenced by factors such as the economic and cultural similarity between source and destination countries (Chiswick, 1979). The larger those differences are the more immigrants lack country-specific skills and information which harms their immediate labor market prospects. Alone, lower returns to foreign human capital were found to fully explain the earnings disadvantage of immigrants as compared to those earned by similar native workers (Friedberg, 2000). The difficulty of finding jobs in high-skilled occupations leads high-skilled immigrants to accept job offers in low skilled occupations, thereby magnifying the depreciation of the human capital acquired at home.

Occupational downgrading may be optimal if combined with on-the-job search which, with time, permits immigrants to find better matches and receive higher wages (Weiss et al., 2003). Mobility up the occupational ladder alongside with rising returns to imported and local human capital are the three major sources of wage growth for immigrants. The national origin of an individual's human capital (Friedberg, 2000), language skills (Chiswick and Miller, 2002), training and experience acquired locally (Cohen and Eckstein, 2002) and clustering into ethnic enclaves (Borjas, 2000), all have been found to play a role in the process of economic assimilation of immigrants.

In this article we contribute to the vast literature on the economic assimilation of immigrants at destination by focusing on a new host country and by using matched employer-employee data instead of the more widely used employee-level data.

Most stylized facts in the economic migration literature were derived from the analysis of countries with a long tradition as hosts of international migrants. However, as international migration flows went through major changes in recent years, a number of new destinations emerged. In Europe, this was notably the case of Southern countries - Italy, Spain, Greece and Portugal - all of which have a long tradition as sending nations.

In this paper we focus on the case of Portugal. We offer evidence that allows us to put immigrants economic performance in a new destination country against the background of other countries with a longer history of inward migration. This is the first contribution of the article.

Throughout the article, we use matched employer-employee data. Although we do not claim that these data are universally superior to the more widely used employee data, we do show that some important and previously neglected questions are best answered with these data. Specifically, we are able to control for employer and match characteristics in the estimation of wage equations. By using such data we are also able to address the topic of immigrant concentration in the workplace and thereby assess the role that factors such as discrimination and 'ethnic goods' 
play in shaping the earnings of immigrants. ${ }^{1}$ This is the second contribution of the article.

The paper is outlined as follows. Section 2 briefly describes the evolution of immigration to Portugal in recent years. Section 3 presents the dataset. In section 4 an estimate of the wage disadvantage of immigrants is obtained and its variation over the entire distribution of wages is analyzed - the importance of minimum wage legislation at the left-tail of the distribution is illustrated. In section 5 we look at the effect of the concentration of immigrants at the workplace on their earnings. Section 6 concludes.

\section{The Immigration Record}

Portugal's position in the context of international migrations changed dramatically in the late 1990s as was also the case with other Southern European countries (see Venturini, 2004). Portuguese nationals have been leaving the country predominantly for work-related reasons at least since the mid-eighteenth century first towards the Americas (specially Brazil) and after World War II towards Continental Europe, specially France and Germany. As a result of this sustained flow of migration over such a long period of time, it is estimated that as many as 4 million Portuguese citizens (about 40 percent of the total population residing in the country) currently lives abroad.

However, the economic recession in Europe in the early 1970s and the change of political regime in 1974 in Portugal combined to originate a reduction in outmigration. It was also during these years that Portugal had its first experience as a region of inward migration following the independence of the country's former colonies in Africa (see Carrington and Lima, 1996).

Ever since that time, the number of foreign nationals living in Portugal increased steadily (see Figure 1). Net immigration became positive in 1993, and there has been a large increase in the number of immigrants arriving in Portugal since the end of the twentieth century which was also accompanied by a change in the composition of the flow of immigrants.

The changes we observed in Portugal are part of a larger process of recomposition of migration flows worldwide. As the proportion of European immigrants increased during the 1990s following the opening of the Eastern European borders, the same happened in Portugal where immigrants arriving from Portuguese speaking nations (in Africa or from Brazil) were out-numbered by those arriving from such countries as Ukraine and Moldova. Other countries in Asia (China, India and Pakistan) also contributed with a growing number of immigrants. However, immigrants arriving in Portugal differ from those choosing to migrate to other more developed countries in the OECD area because they are younger and they have lower levels of education even comparing to natives. They are also predominantly migrants for employment-related reasons. Asylum-seekers and refugees as well as immigrants entering through family reunification programs are less numerous here than elsewhere (see SOPEMI, 2002, p.21). Although such migration patterns are not common in most OECD countries, they are also noticed in other Southern European countries where it is also the case that cultural and linguistic affinity

\footnotetext{
${ }^{1}$ These data are not without problems. The most severe is perhaps the lack of information on the family status of the worker. Although the results obtained are in the same ballpark as indicated by other studies that use employee data.
} 
Figure 1: Stock of immigrants With a VAlid RESidence CARD (1981-2006) - SourCe: SEF - Serviço de Estrangeiros e Fronteiras

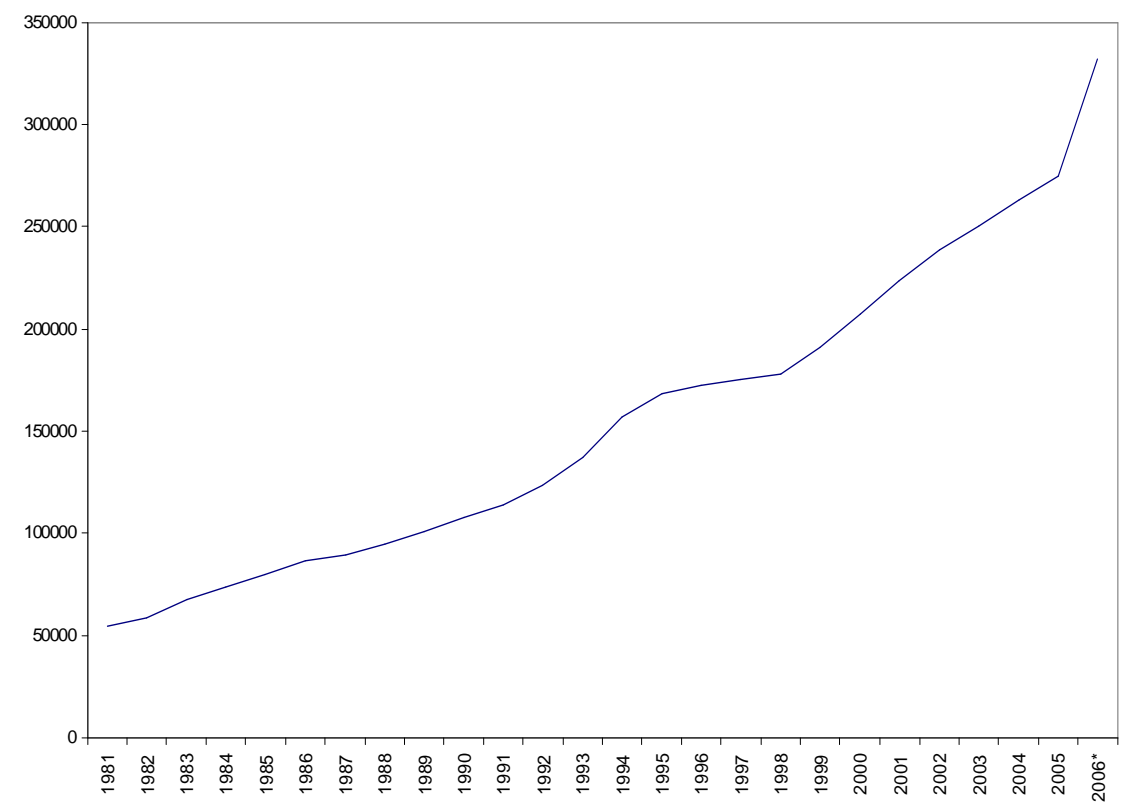

between sending and receiving regions is weaker for more recent immigration cohorts.

\section{The Data}

The data set used in this study comes from Quadros de Pessoal $(Q P)$. $Q P$ is an annual mandatory employment survey collected by the Portuguese Ministry of Labor, that covers virtually all establishments with wage earners. ${ }^{2}$ Each year every establishment with wage earners is legally obliged to fill in a standardized questionnaire. By law, the questionnaire is made available to every worker in a public space of the establishment. This requirement facilitates the work of the services of the Ministry of Labor that monitor employers compliance with the law (e. g., illegal work). The administrative nature of the data and its public availability imply a high degree of coverage and reliability.

Reported data cover the establishment itself (location, economic activity and employment), the firm (location, economic activity, employment, sales and legal framework) and each of its workers (gender, age, education, skill, occupation, tenure, earnings and duration of work). The information on earnings is very complete. It includes the base wage (gross pay for normal hours of work), regular and irregular wage benefits and overtime pay. Information on normal and overtime hours of work is also available. In fact, one of the main advantages of this data

\footnotetext{
${ }^{2}$ In general, public administration and non-market services are excluded.
} 
set is to have information at both individual and firm levels and to match workers with their employers.

Even though the Ministry of Labor has been conducting this survey since 1982, the 2000 wave is the first to have information on the worker's nationality. ${ }^{3}$ Data to this study were available until the year 2004 with the exception of the 2001 wave. Because all information is reported by the employer there is no information in the data about the timing of foreign workers entry to the country. However, the first time an individual enters paid employment (legally) he or she also enters the database. At that moment they are given an identification number that is unique and remains constant over time. We made use of this property of the data to identify as accurately as possible the timing of entry into (formal) employment of each immigrant worker. To do that we constructed a panel of employees starting in 1991 and traced each non-national worker present in the data at least once in 2003 and 2004 back to its first record. We take the year of that worker-specific first record as a proxy to the immigrant's time of entry to the country and start counting the length of stay in the country at that moment (duration is censored at 13 years). By proceeding this way we aim at minimizing the impact of the absence of direct information on the time of arrival to the country.

We restrict our sample to non-apatrid workers aged between 16 and 64 years. Because we use first lagged variables in regression analysis and the 2001 wave of the data is not available we only use observations drawn from the 2003 and 2004 waves. After excluding all observations with missing values on the explanatory variables used in regression analysis and the outliers in wages (1\% top and bottom observations), we obtained a sample that contains a total of 3.8 million observations (years $\times$ individuals), approximately 1.9 million per year, corresponding to $1,414,244$ male workers and to $1,039,514$ female workers. ${ }^{4}$

Of the total number of records, 156,224 correspond to non-Portuguese citizens and are therefore classified as immigrants. Consistent with the evolution of the number of foreign citizens residing in the country, the number of immigrants in the dataset also increases from 71,818 in 2003 to 84,406 in 2004. Sample means for the two groups of workers (native-borns and immigrants), as well as for selected groups of nationalities are presented separately for men and women in Tables A.1 and A.2 of Appendix A.

Foreign workers account for 4.1 percent of total employment in the private sector of the economy. The corresponding figures for men and women are 4.8 percent and 3.2 percent, respectively. Employed immigrants from the former Soviet Union nations are the most numerous group. They account for 38.1 percent of all immigrants in the country (43.6 percent if we consider male immigrants only). They are followed at some distance by immigrants from the former Portuguese colonies in Africa (which were traditionally dominant and now account for as much as 25 percent of the total) and from Brazil (17.6 percent of the total). EU14-nationals (i.e. citizens of the EU15 excluding Portugal) represent a small minority of all foreigners working in Portugal (6.2 percent). ${ }^{5}$

\footnotetext{
${ }^{3}$ The nationality of the worker is the only information available that helps to identify migrant workers. For that reason, throughout the article, we take the word immigrant as synonimous of non-national citizen. This is not our preferred option. However, given the fact that large inflows of migrants are new to Portugal we believe that this is not an unsurmountable obstacle.

${ }^{4}$ Whenever a worker was present in one wave of the QP dataset more than once we only kept the register corresponding to the establishment where he or she was working more hours.

${ }^{5}$ For a description of the composition of each nationality group, see notes to Tables A.1 and A.2 in Appendix
} 
Comparing male immigrants and male native workers we find that the average age of immigrants (35.4) is less than it is for natives (36.4). Immigrants are less educated and they are allocated to positions closer to the bottom-end of the skills distribution. ${ }^{6}$ Tenure of immigrant male workers is 1.9 years, 5.9 years below the natives' average. This reflects the recent nature of immigration to Portugal as well as immigrants' weaker attachment to employment. Tenure is specially short for immigrants arriving from Brazil (1.3 years).

The unconditional average of immigrants' hourly wage is less than the natives average for all nationality groups except the EU14. The lowest average wages are recorded for the group of the former USSR nationals (0.95 and 0.89 Euros per hour (in logs) for men and women, respectively) and for the Chinese (0.79 and 0.77 Euros per hour (in logs) for men and women, respectively). About 10 percent of all male immigrants (24.6 percent in the case of women) receive the minimum wage.

The sectoral distribution of immigrant employment differs markedly between men and women. Male immigrants are predominantly employed in the construction industry (39.2 percent) and in manufacturing (18.7 percent). Female immigrants concentrate in wholesale, retail trade \&

hotels sectors (39.0 percent), and in banking, insurance and services to firms (28.5 percent) which includes temporary help agencies and cleaning services.

\section{The magnitude of the immigrant wage gap}

The standard approach to the study of the earnings of immigrants is based on the estimation of a human capital earnings function (Mincer, 1974) augmented to include immigrants experience in the host labor market (Chiswick, 1978). Typically, studies that proceed along these lines use data from national labor force surveys or censuses of population. For that reason, the wage functions that underlie such studies are standard Mincerian equations that are occasionally augmented to include (whenever available) some measure of the destination language fluency, minority language concentration in residential areas and indicators of the country of origin of the immigrant (e.g., Chiswick and Miller, 2002).

The type of data available for the study of immigrants' earnings does not allow us to control for the characteristics of the workplace which are known to be important determinants of earnings. However, being able to control for such characteristics is essential for decomposing the earnings gap into its two components: wage discrimination and segregation across establishments and occupations.

In this section we report the results of the estimation of wage equations for the entire population of wage-earners in the Portuguese private sector for the 200304 period (Table 1). We start with a parsimonious specification (specification 1) that controls only for the demographic characteristics of workers (age, nationality status, the proxy for time since arrival to the country, and the region of work), education and time-effects. ${ }^{7}$ Although we are not able to control for some characteristics that are included in most available studies (specially, family status) we

${ }^{6}$ Each worker is administratively assigned to one skill level out of eight possible: Highly Professional, Professional, Supervisor, Highly-skilled, Skilled, Semi-skilled, Unskilled and Apprentices. Assignment is determined exclusively on the basis of the workers' occupation and educational level.

${ }^{7}$ For a definition of the variables see Appendix B.
} 
view this specification as the equivalent to the ones most widely used in previous research.

Our interest is in the estimates of the coefficients of three covariates: one dummy variable - IMIG - indicating nationality status (equal to one if the worker is a nonnational citizen), one variable measuring the number of years since the worker first entered the database (years since migration) taken as a proxy for experience accumulated in the Portuguese labor market - $Y S M$ - and one variable capturing the concentration of immigrants at the workplace as measured by the proportion of all workers in the establishment that are non-national citizens - LPIMIGE. ${ }^{8}$ All equations were estimated separately for men and women.

The results in the second column of Table 1 point to male immigrants' earnings being at the time of entry approximately 31.6 percent below the earnings of similar natives. ${ }^{9}$ Although on the high-side, this result is in line with previous estimates reported for the relative wage of immigrants in other countries such as the U.S., Canada or Israel. The corresponding figure for female immigrants is -19.8 percent.

Table 1: Pooled OLS wage regression (selected estimates), 2003-04 Dependent variable: log of real hourly wage

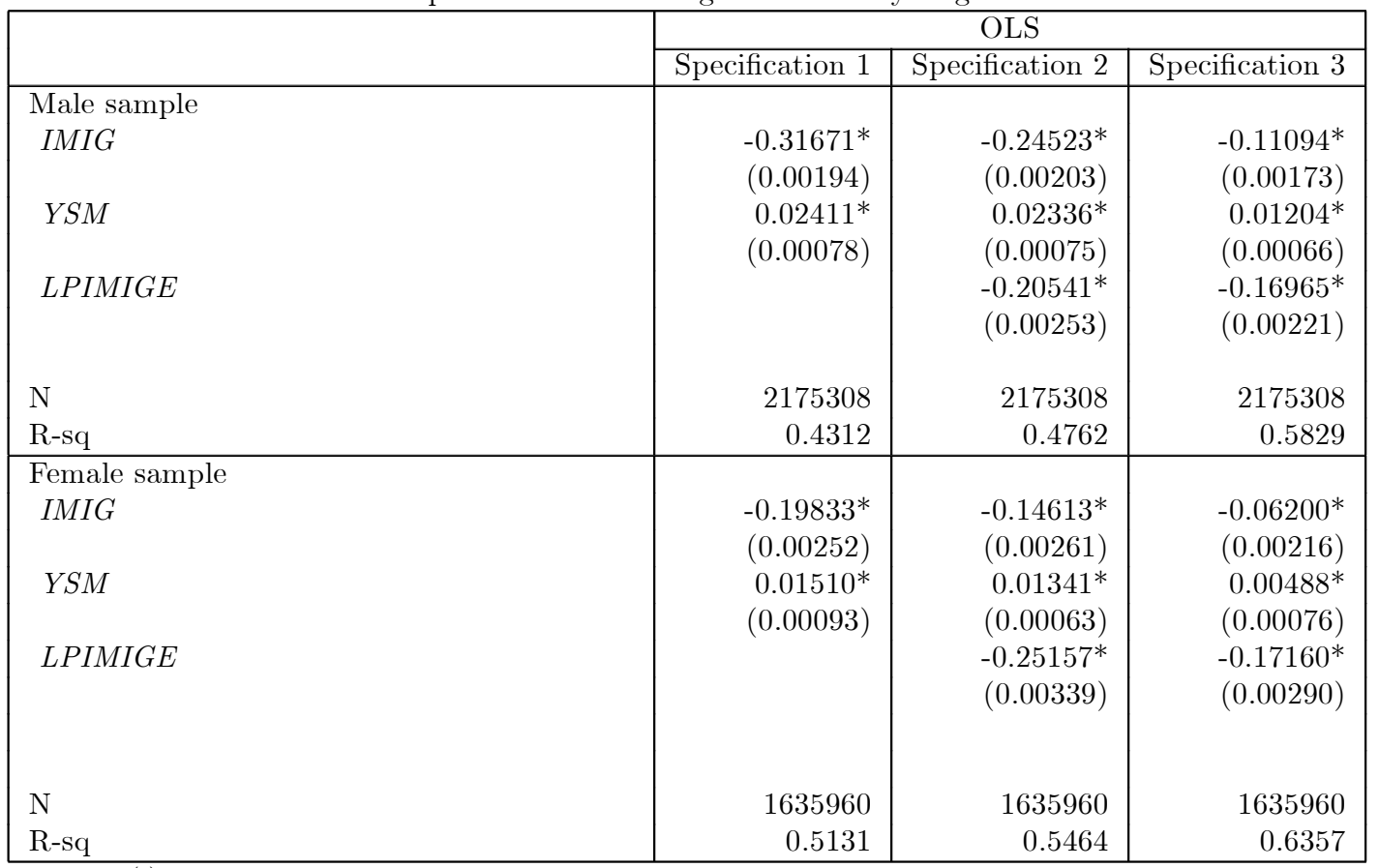

Notes: (i) robust cluster standard errors in parentheses;

(ii) $*, * *, * * *$ denotes significant at $1 \%, 5 \%$ and $10 \%$, respectively.

\footnotetext{
${ }^{8} \mathrm{We}$ measure immigrant concentration as the share of workers in the establishment that are non-national citizens. To minimize potential endogeneity problems we use the first lag of this variable measured at the establishment level, meaning that for worker $i$ in establishment $j$ in year $t$ the immigrant concentration variable measures the proportion of immigrant workers in establishment $j$ in year $t-1$ even if worker $i$ was working at a different establishment in year $t-1$ or he or she had not entered the country at that time.

${ }^{9}$ In Table 1 we only report the estimates for the coefficients of interest. The full set of results is reported in Tables C.1 and C.2 in Appendix C, for men and women, respectively.
} 
Approximately one quarter of the immigrants' earnings gap disappears if we control for such employer characteristics as size, industry and workplace concentration of non-national workers (specification 2). Put differently, one quarter of the conditional wage difference between native and non-native workers can be attributed to the characteristics of the workplace such as industry, establishment size and immigrant concentration.

If we include in the set of regressors, as we do in specification 3, controls for match-specific characteristics such as tenure and skill categories, the earnings gap of immigrants at the time of entry to the Portuguese labor market is reduced to -11.1 and -6.2 percent for male and female workers,

respectively, which is the equivalent to one third of the corresponding estimate obtained with specification 1 . This result indicates that the difference upon arrival in the earnings of immigrants and natives with similar personal characteristics is for the most part due to the characteristics of the matches they form, immigrants being penalized on two different counts: absence of match-specific human capital (as they have just entered the country) and occupational downgrading. The sensitivity of the estimate of the coefficient of the immigrant status variable to the inclusion of the occupational dummies indicates that immigrants work at lower levels of the occupational-ladder than similar natives working for similar employers. Considering that high-skilled immigration is a recent phenomenon in Portugal, this is consistent with Eckstein and Weiss (2004) who note that, upon entry, immigrants from the former Soviet Union to Israel experience substantial occupational downgrading - half of the male immigrants with more than 16 years of schooling work in low-skill occupations during the first three years in Israel. Green (1999) also reports substantial occupational mobility (away from nonemployment and less skilled occupations) of immigrants during their first years of stay in Canada.

The estimate of the coefficient of the variable that measures the immigrants' length of stay in Portugal also indicates that the wage progress of immigrants is accounted for by both within-job and between jobs mobility. For men, our baseline estimate indicates that immigrants wages grow above similar natives' wages at 2.4 p. p. per year spent in the host country. However, this estimate drops off to 1.2 p.p. when controls for match-specific characteristics (including occupational categories) are considered.

The penalty on the wages of immigrants is not constant over the wage distribution. The results obtained by estimating quantile wage regressions (Koencker, 2005) adopting the same specification as specification 3 in Table 1 indicate that the wage penalty received by male immigrants increases steadily over the entire distribution of wages, from a minimum of 0.07 at the first decile to a maximum of 0.13 at the ninth decile - Figure $2 .{ }^{10}$ For women, the pattern is similar although with a difference at percentile 9 .

The fact that immigrants do relatively better at the lower-end of the wage distribution may be the consequence of mandatory minimum wage rules that have been in place in Portugal since as early as 1974 and that are actually binding both in terms of wages and employment opportunities (Portugal and Cardoso, 2006,

\footnotetext{
${ }^{10}$ Throughout the paper we refer to the immigrants' wage penalty as the absolute value of the coefficient of the immigrant status dummy variable in the wage equation.
} 
Figure 2: Estimated immigrants' wage Penalty - Quantile Regressions (dotted lines represent the width of the confidence interval at 95 percent)

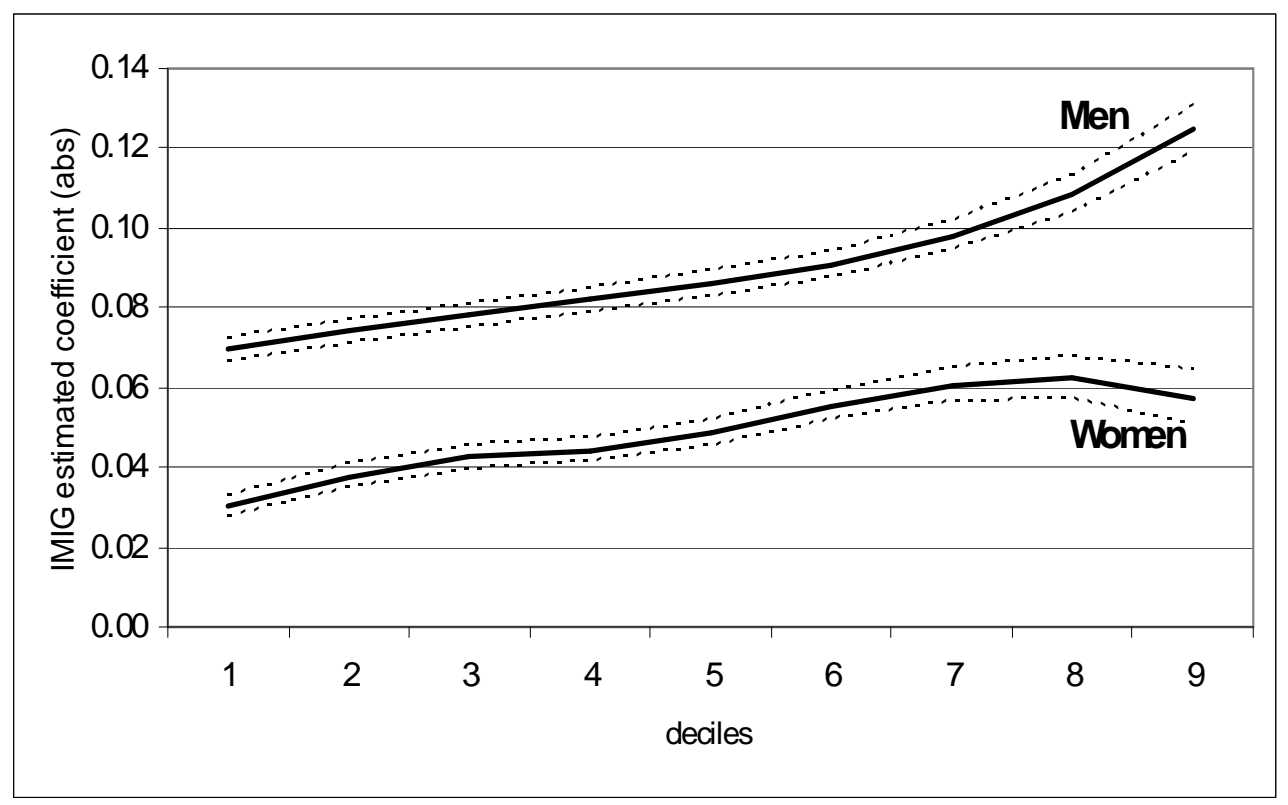

Pereira, 2003). If we look at the wages immigrants are paid in the Portuguese labor market we find that 10.4 percent of the males and 24.6 percent of the females receive the legal minimum (for natives the corresponding figures are 5.5 percent and 12.9 percent), respectively (see Tables A.1 and A.2 in Appendix A).

Results in Table 1 also show that the concentration of immigrants at the establishment has a significant effect on wages. From specification 3 the estimated effect of a one percentage point increase in the proportion of the establishment's workforce who are non-nationals reduces wages by 0.17 percent for both male and female workers. Still, the magnitude of this effect also varies considerably across the wage distribution - it is minimum at the first decile and increases until we reach the seventh deciles for both men and women (Figure 3).

\section{Workplace concentration of immigrants and wages}

There are two reasons why a greater presence of immigrants in the workplace may bring about a reduction in wages. The first is a standard compensating wage differential reason. Immigrant workers may be willing to pay to work with other immigrants. To the extent that these co-workers have the same national origin or cultural background several factors can explain why immigrants would be willing to accept lower wages to work in such environments, ranging from (workplace) ethnic goods (common language, working habits, etc) to search economies or herd behavior. 
Figure 3: Estimated coefficient of LPIMIGE - Quantile Regressions

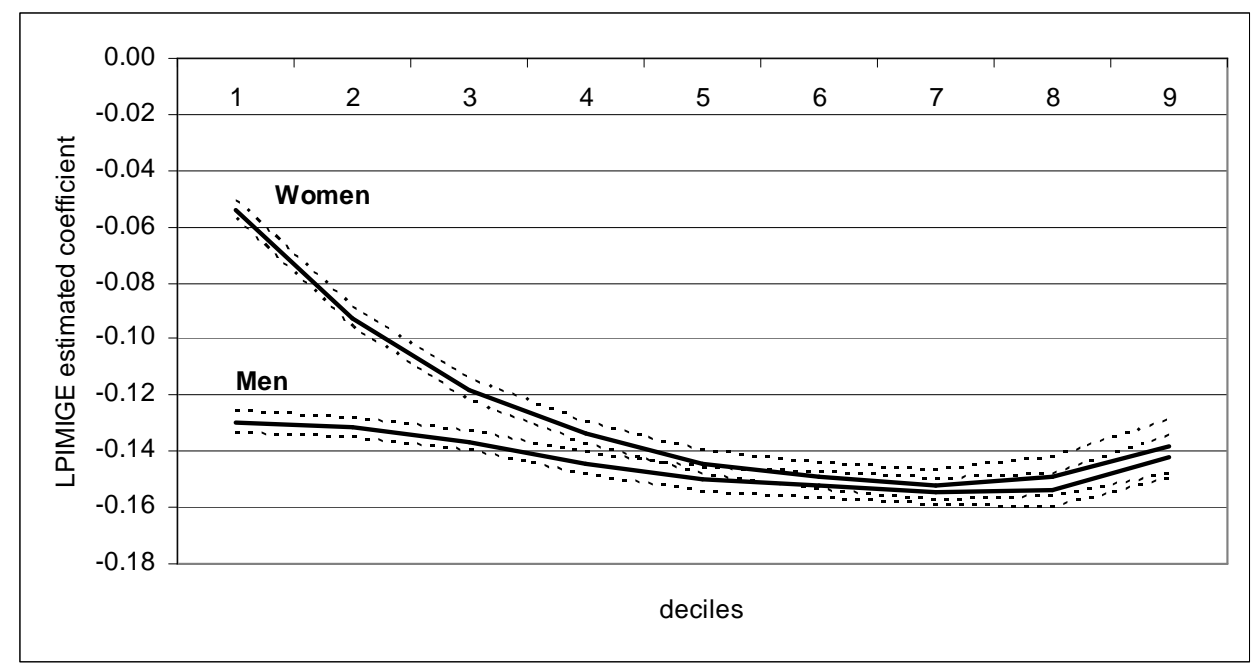

However, the same result is also consistent with a discrimination-crowding explanation. According to this explanation immigrants earn lower wages because they work in specific occupations and/or for specific employers. Segregation occurs for several reasons. Discriminatory behavior by employers is one of them. But statistical discrimination or discriminatory behavior by fellow employees are equally admissible causes of the same fact. Statistical discrimination in particular is consistent with a number of stylized facts in the literature on the economic assimilation of immigrants, most notably the fact that immigrants' entry into host labor markets is made more difficult when the cultural distance between home and host countries is greater and the fact that the imperfect portability of human capital across countries reduces wages immediately upon arrival in the country with some part of the gap being closed after a few years of the stay. Note that the statistical discrimination hypothesis crucially depends on the assumption that employers' ability to screen workers varies across groups (cultural distance making the assumption more reasonable) and it implies that the greatest impact of this type of discrimination is on entry-level wages.

Admittedly the results we obtained in the previous section do not allow us to disentangle the two sets of arguments. To do that we re-estimated the wage equation corresponding to specification 3 in Table 1, separately for immigrants and natives (men and women). The estimates we obtained for the coefficient of the workplace immigrant concentration variable (LPIMIGE) are reported on Table $2 .^{11}$

\footnotetext{
${ }^{11}$ Full results are presented in Table D of Appendix D.
} 
Table 2: Pooled OLS wage regression (selected estimates), 2003-04 Dependent variable: log of real hourly wage

\begin{tabular}{|c|c|c|}
\hline & Immigrants & Natives \\
\hline \multicolumn{3}{|l|}{ Male sample } \\
\hline LPIMIGE & $\begin{array}{c}-0.1410^{*} \\
(0.0030)\end{array}$ & $\begin{array}{c}-0.1950^{*} \\
(0.0030)\end{array}$ \\
\hline $\mathrm{N}$ & 103598 & 2071710 \\
\hline R-sq & 0.5009 & 0.5823 \\
\hline \multicolumn{3}{|c|}{ Female sample } \\
\hline LPIMIGE & $\begin{array}{c}-0.0771^{*} \\
(0.0050)\end{array}$ & $\begin{array}{r}-0.2315^{*} \\
(0.0036)\end{array}$ \\
\hline $\mathrm{N}$ & 52626 & 1583334 \\
\hline $\mathrm{R}$-sq & 0.5579 & 0.6385 \\
\hline
\end{tabular}

Notes: (i) robust cluster standard errors in parentheses;

(ii) $*, * *, * * *$ denotes significant at $1 \%, 5 \%$ and $10 \%$, respectively.

The first thing to notice from Table 2 is that the estimated coefficient of the $L P I M I G E$ in the immigrants' wage equation is indeed negative and significant. The estimated wage of male immigrant workers drops off 0.14 percent for each percentage point increase in the share of non-national workers in the establishment. The corresponding figure for female immigrants is -0.07 percent. As explained, this result is not sufficient to tell whether this is due to the compensating wage differential mechanism or if it has a discrimination interpretation.

However, as seen from the second column of Table 2, the estimated coefficient for the same variable in the native workers equation - male or female - is also negative and statistically significant. This result rules out the compensating differential interpretation as there is no reason why native workers would be willing to accept substantial wage reductions to work with non-native fellow workers. ${ }^{12}$

These results are not consistent with the compensating wage differential story as both immigrants and natives' pay diminish with the share of immigrants at the workplace. Besides, compensating wage differentials are equilibrium outcomes that are less likely in a labor market where large-scale immigration is a recent phenomenon. On the contrary, discrimination-driven wage differentials are a disequilibrium outcome and because of that they are more likely in situations such as that of the Portuguese labor market. Results in Table 2 rule out employee discrimination as this would imply a positive (not negative) sign for the coefficient of the immigrant concentration variable in the native wage equation. The results we obtained indicate that the reason immigrants receive lower wages than otherwise similar native workers is because they are working for different employers,

\footnotetext{
${ }^{12}$ Nepotism could arguably have produced the same effect but the estimated coefficients are far too large to believe that this is the case. In any case, nepotistic behavior is less common among low-wage workers. This type of behavior is more frequently referred to amongst high-skilled white-collar workers in intellectual or scientific occupations (although not in the context of wage studies). The results of quantile regression estimation (Figure 3 ) indicate otherwise - the magnitude of the effect of workplace concentration for the pooled sample of natives and immigrants increases as we move to the right of the wage distribution.
} 
employers that pay lower wages to all their workers, natives or not. ${ }^{13}$ Therefore, we conclude that the wage penalty immigrants receive is the immediate result of their being segregated into the low pay sector of the economy due to employer discrimination. From our results alone, we cannot tell whether such discriminatory behavior is grounded in statistical discrimination type of arguments (which could be explained by the fact that the latest and largest cohorts of immigrants are arriving from more diversified origins than previously) or whether it is the result of pure prejudice against non-native workers (an explanation that cannot be ruled out considering that this is a recent phenomenon and for that reason consistent with disequilibrium outcomes).

Two further pieces of evidence can be put forward in support of the same interpretation. The first are the results obtained for the same specification of the wage equation when we control for nationality groups. The compensating wage differential explanation is more likely (and the employer discrimination explanation less likely) when the group of immigrants belong to a group with a similar cultural background. Native language being the single most important factor determining the proximity between origin and destination, we would expect that workers originating from the Portuguese former colonies in Africa (including East Timorese in this group) and from Brazil to be the least prone to look for being close to other immigrants and for that reason to accept lower wages to work with their similars. This is not what we observe.

The distribution of immigrants originating from the Portuguese former colonies in Africa, East Timor and Brazil across workplaces with varying levels of immigrant concentration does not differ markedly from the distribution of the entire population of immigrants working in Portuguese territory (Figure 4 and Tables A.1 and A.2 in Appendix A). There are, however, some differences between the two groups considered. African immigrants seem to concentrate in more immigrantpopulated workplaces than Brazilian immigrants. This is valid for both men and women. The average proportion of immigrants in workplaces where African men are working is 42.9 percent, $4 \mathrm{p}$. p. above the corresponding figure for the entire group of male immigrants (38.9 percent). In contrast for Brazilian males, the average proportion of immigrants in the workplaces where they are employed is 35.2 percent. ${ }^{14}$

By looking at the distribution of the share of immigrants at the workplace for these two groups it becomes apparent that the observed differences in the means are due to differences in the tails of the two distributions - a greater share of Brazilians work in establishments where foreign workers account for less than 10 percent of the total and a smaller share of them work in establishments where immigrants represent more than 90 percent of the total number of employees. This pattern,

\footnotetext{
${ }^{13}$ The establishment fixed effects results presented in Appendix $\mathrm{C}$ corroborate this idea. Actually, when an establishment fixed effect is added to specification 3, the immigrant wage penalty is reduced by around $3 \mathrm{p}$. p. for both men and women. Notice also that the estimates for the coefficient of the workplace immigrant concentration variable (LPIMIGE) are substantially reduced. Nevertheless, we cannot interpret this result as indicating a strong correlation between this variable and establishment unobserved characteristics, because the impact of LPIMIGE is identified only for those establishments that experienced a variation in workplace concentration over the two-year period and this corresponds to a small proportion of our sample.

${ }^{14}$ For women, the average share of immigrants in the workplace is 35.0 percent, 33.1 for the Africa \& East Timor group and 33.9 percent for the Brazilian group.
} 
Figure 4: Distribution of LPIMIGE For the groups of AFrican \& E. Timorese, and BRAZILIAN IMMIGRANTS
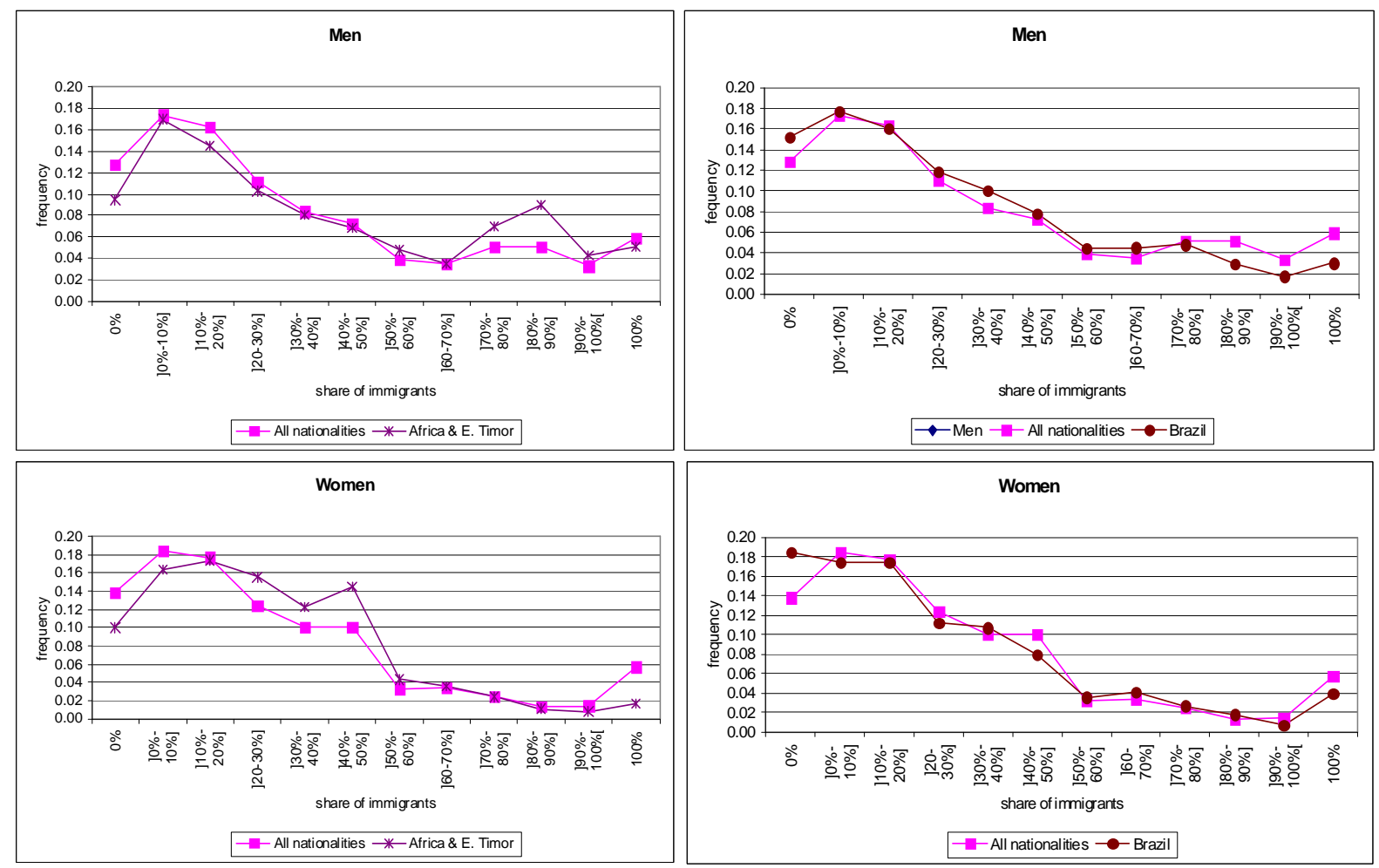
which is common to the male and female distributions, is totally reversed when we consider immigrants originating in Africa \& East Timor.

Although the distribution of Brazilian and African immigrants across workplaces is not similar (closer to what is warranted by cultural proximity in the case of Brazilians), we do not find any evidence of either group being willing to pay less to work with other immigrants as it would be implied by most existing studies on ethnic segregation and cultural proximity.

Running the same wage regressions as in Table 2 but including dummy variables for nationality groups and interaction terms between the latter and immigrant concentration (the omitted category is UE14) we find, in the case of men, that the two Portuguese-speaking groups are the ones for which we observe a greater reduction in wages when the share of immigrants at the workplace increases (Table 3 ). For women this is also true although the interaction terms coefficients are not statistically significant at the conventional levels.

Table 3: Pooled OLS wage regression (selected estimates), 2003-04

Dependent variable: log of real hourly wage

\begin{tabular}{|c|c|c|}
\hline & Males & Females \\
\hline \multirow{2}{*}{$L P I M I G E$} & $-0.2460 *$ & $-0.0494^{* * *}$ \\
\hline & $(0.0292)$ & $(0.0268)$ \\
\hline \multirow[t]{2}{*}{ Former USSR } & $-0.2948^{*}$ & $-0.2097^{*}$ \\
\hline & $(0.0107)$ & $(0.0109)$ \\
\hline \multirow[t]{2}{*}{ Africa $\&$ East Timor } & $-0.2507^{*}$ & $-0.1830^{*}$ \\
\hline & $(0.0111)$ & $(0.0111)$ \\
\hline \multirow[t]{2}{*}{ Brazil } & $-0.2320^{*}$ & $-0.1788^{*}$ \\
\hline & $(0.0112)$ & $(0.0112)$ \\
\hline \multirow[t]{2}{*}{ China } & $-0.3783^{*}$ & $-0.3011^{*}$ \\
\hline & $(0.0208)$ & $(0.0231)$ \\
\hline \multirow[t]{2}{*}{ Other Nationalities } & $-0.2413^{*}$ & $-0.1496^{*}$ \\
\hline & $(0.0114)$ & $(0.0127)$ \\
\hline \multirow[t]{2}{*}{$L P I M I G E \times$ Former $U S S R$} & $0.1749^{*}$ & 0.0203 \\
\hline & $(0.0295)$ & $(0.0275)$ \\
\hline \multirow[t]{2}{*}{ LPIMIGE $\times$ Africa $\&$ East Timor } & $0.076^{* *}$ & -0.0449 \\
\hline & $(0.0297)$ & $(0.0279)$ \\
\hline \multirow[t]{2}{*}{$L P I M I G E \times B r a z i l$} & $0.1018^{*}$ & -0.0439 \\
\hline & $(0.0301)$ & $(0.0282)$ \\
\hline \multirow[t]{2}{*}{$L P I M I G E \times C h i n a$} & $0.1651^{*}$ & 0.0302 \\
\hline & $(0.0352)$ & $(0.0351)$ \\
\hline \multirow[t]{2}{*}{ LPIMIGE $\times$ Other Nationalities } & $0.0727^{* *}$ & -0.0404 \\
\hline & $(0.0301)$ & $(0.0331)$ \\
\hline $\mathrm{N}$ & 103,598 & 52,626 \\
\hline R-sq & 0.5204 & 0.5751 \\
\hline
\end{tabular}

(ii) $*, * *, * * *$ denotes significant at $1 \%, 5 \%$ and $10 \%$, respectively.

There is information contained in the pattern of variation over the wage distribution of the estimated coefficient of the LPIMIGE if quantile wage regressions are estimated separately for each nationality group. The results concerning the 
Figure 5: Estimated COEFFICIENT of LPIMIGE - QUANTILE REGRESSiOnS By NATionality GROUP (MEN)

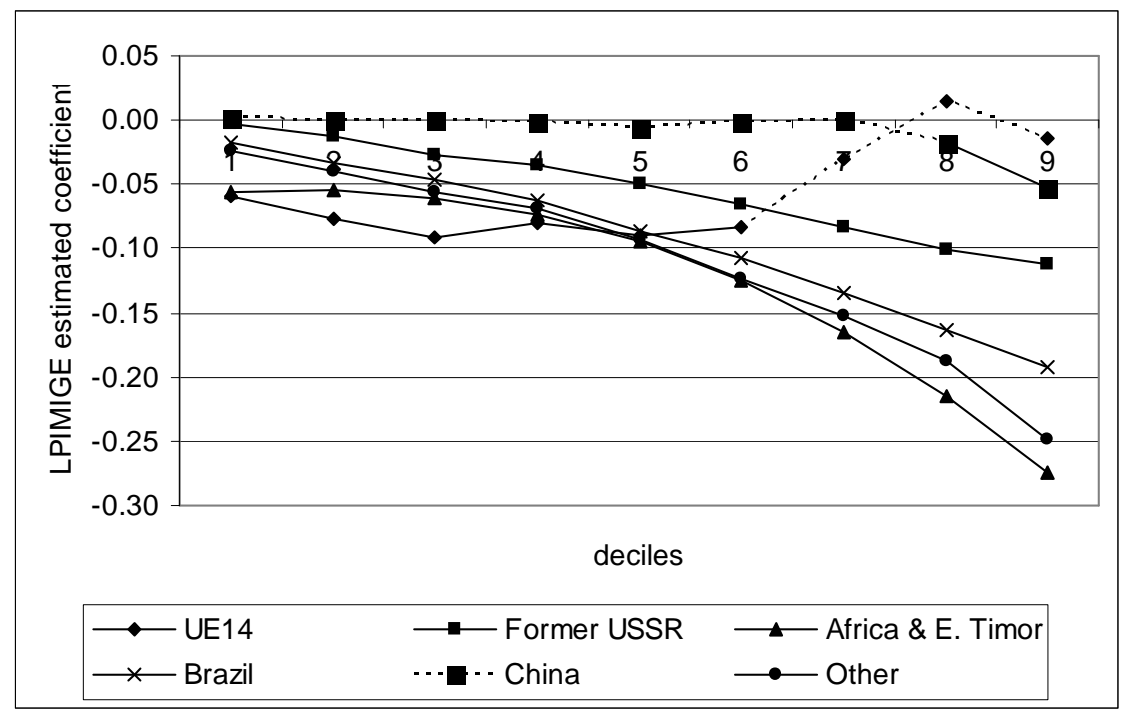

variable of interest are plotted in Figure 5 where a dashed line means that the corresponding estimate is not significantly different from zero at the 10 percent level of significance (all the other estimates are significant at 1 percent). ${ }^{15}$

Only two nationality groups escape the dominant pattern of variation of the estimate for the LPIMIGE variable that was depicted in Figure 3. One - the Chinese group - is virtually constant and equal to zero up to the seventh decile. However, in this case the small size (1,377 observations) of the underlying sample clouds the interpretation of this result. The other group is the group of the EU14 national citizens. For these individuals, the wage penalty for each percentage point increase in the share of immigrants in the workplace varies between six and nine percent in the bottom half of the distribution and becomes null at the top-half. From a sociological point of view this pattern is consistent with a compensating differential interpretation, although it does not rule out competing interpretations. It flows from existing theories of socio-behavioural processes that in a society where members are ranked according to a quantitative characteristic such as income and which has two (or more) subgroups based on nationality or ethnicity for example, the bottom subgroup is less devoted to its own subgroup than the top subgroup (see Jasso, 2008). Hence, you would expect that as we approach the top-end of the wage distribution individuals would become less willing to pay to work with members of the same sub-group. Figure 5 shows that to all, but for the two nationality groups mentioned above, this is not the case. For these other nationality groups (and specially for immigrants originating from Portuguese former colonies) the wage penalty associated with working with other immigrant increases over the wage distribution. This is yet another piece of evidence that works against the

\footnotetext{
${ }^{15}$ We only report the results for male samples.
} 
compensating differential interpretation of our result.

\section{Conclusion}

Portugal's history as destination country for international migrants is recent. However, similar to other countries with long immigration records, it is also the case here that immigrants are paid below the wage of similar native workers, the difference being similar to what has been found in previous studies for those other nations.

Notwithstanding, our results also show that the magnitude of the gap is very sensitive to the inclusion of controls for job and match characteristics. This result indicates that, upon arrival, earnings differences between migrants and nonmigrants are mostly due to the characteristics of the match they form, occupational downgrading playing a major role.

One interesting feature of matched employer-employee data is that they allow us to know how immigrants are sorted across workplaces. Similar to what we know about residential concentration, we found that immigrants are also highly concentrated in a relatively small number of establishments.

Immigrants' wages diminish as the share of non-native workers at the workplace increases. Although this result could have a conventional compensating wage differential interpretation, several facts indicate otherwise. First, it is also the case that natives' wages diminish when the number of their non-native co-workers increase. Second, immigrants who share with natives the same native language (i.e., Brazilians and immigrants from the former Portuguese colonies in Africa), make choices concerning working with natives or non-natives that are no different from those made by other groups of immigrants. Third, if anything, the wage penalty due to work with more non-natives is higher for these two groups than for most other groups considered. Fourth, the negative effect of immigrant concentration on immigrants' wages is higher at the top of the wage distribution for all nationalities but the Western Europeans (i.e., those originating in the EU14 group of nations). We conclude that immigrants segregation into low-wage workplaces is the main reason behind the negative association between their wages and the number of immigrants they work with. 
APPENDIX A - Descriptive Statistics

Table A.1: Sample means 2003-04 - Men

\begin{tabular}{|c|c|c|c|c|c|c|c|c|}
\hline \multirow[b]{2}{*}{ Variables } & \multirow[b]{2}{*}{ Natives } & \multirow[b]{2}{*}{ Immig. } & \multicolumn{6}{|c|}{ Groups of Immigrants } \\
\hline & & & EU14 & $\begin{array}{c}\text { Former } \\
\text { USSR }\end{array}$ & $\begin{array}{l}\text { Africa \& } \\
\text { E.Timor }\end{array}$ & Brazil & China & Others \\
\hline Age (in years) & 36.4 & 35.4 & 36.7 & 36.6 & 36.0 & 32.3 & 34.3 & 33.8 \\
\hline \multicolumn{9}{|l|}{ Years since migration (\%) } \\
\hline$\leq 5$ & & 86.3 & 58.8 & 93.5 & 68.8 & 93.5 & 91.2 & 90.8 \\
\hline$>5$ and $\leq 10$ & & 6.1 & 21.6 & 1.8 & 15.4 & 2.8 & 6.7 & 4.3 \\
\hline$>10$ & & 7.6 & 19.6 & 4.7 & 15.8 & 3.6 & 4.9 & 2.1 \\
\hline Tenure (in years) & 7.8 & 1.9 & 3.9 & 1.8 & 2.5 & 1.3 & 1.5 & 1.5 \\
\hline \multicolumn{9}{|l|}{ Education Levels (\%) } \\
\hline Less than 6 years & 31.1 & 31.7 & 9.7 & 30.8 & 44.1 & 23.6 & 31.6 & 48.9 \\
\hline 6 years completed & 24.3 & 16.5 & 11.2 & 16.6 & 15.5 & 19.4 & 16.4 & 9.7 \\
\hline 9 years completed & 20.5 & 19.4 & 19.6 & 20.4 & 16.0 & 22.1 & 18.3 & 15.0 \\
\hline 12 years completed & 16.2 & 16.1 & 25.8 & 15.2 & 11.8 & 20.8 & 17.4 & 4.8 \\
\hline College education & 7.6 & 4.9 & 26.7 & 3.7 & 3.4 & 3.5 & 4.8 & 1.6 \\
\hline Non-defined & 0.3 & 11.5 & 6.8 & 13.2 & 9.2 & 10.5 & 11.6 & 20.0 \\
\hline \multicolumn{9}{|l|}{ Qualification Levels (\%) } \\
\hline Highly Professional & 5.5 & 2.0 & 17.2 & 0.5 & 1.5 & 1.9 & 1.8 & 2.8 \\
\hline Professional & 4.5 & 1.5 & 13.2 & 0.5 & 1.4 & 1.1 & 1.5 & 1.3 \\
\hline Supervisors & 5.5 & 1.4 & 7.8 & 0.6 & 1.6 & 1.4 & 0.4 & 1.3 \\
\hline Highly Skilled and Skilled & 56.3 & 43.0 & 43.1 & 38.8 & 50.8 & 46.5 & 39.7 & 40.2 \\
\hline Semi-skilled and Unskilled & 21.0 & 39.7 & 12.7 & 47.3 & 32.8 & 34.5 & 39.4 & 42.0 \\
\hline Apprentices & 4.1 & 5.8 & 3.0 & 7.1 & 2.7 & 7.3 & 15.4 & 4.9 \\
\hline Non-defined & 3.2 & 6.7 & 3.9 & 5.1 & 9.2 & 7.4 & 0.8 & 8.5 \\
\hline \multicolumn{9}{|l|}{ Industry $(\%)$} \\
\hline Agriculture \& fishing & 1.6 & 2.8 & 3.0 & 4.0 & 0.4 & 1.4 & 0.6 & 4.6 \\
\hline Mining \& quarrying & 0.8 & 0.8 & 0.8 & 1.3 & 0.3 & 0.3 & 0.0 & 0.4 \\
\hline Manufacturing & 30.0 & 18.7 & 24.0 & 26.8 & 8.8 & 13.4 & 0.9 & 13.6 \\
\hline Electricity, gas \& water & 1.0 & 0.1 & 0.2 & 0.1 & 0.2 & 0.1 & 0.0 & 0.0 \\
\hline Construction & 18.9 & 39.2 & 10.0 & 40.7 & 51.8 & 31.2 & 0.8 & 39.4 \\
\hline Wholesale, retail trade \& hotels & 23.6 & 17.3 & 28.8 & 11.5 & 12.5 & 28.5 & 96.4 & 17.5 \\
\hline Transport, storage \& communications & 8.4 & 4.9 & 6.8 & 5.9 & 3.0 & 5.5 & 0.1 & 3.6 \\
\hline Banking, insurance \& services to firms & 11.2 & 13.5 & 14.0 & 8.3 & 20.4 & 16.3 & 0.4 & 17.6 \\
\hline Community, social \& personal services & 4.3 & 2.8 & 12.4 & 1.5 & 2.7 & 3.3 & 0.7 & 3.4 \\
\hline Plant Size (in logs) & 3.51 & 3.56 & 3.79 & 3.43 & 3.90 & 3.42 & 3.69 & 1.53 \\
\hline Concentration of Immigrants (\%) & 3.1 & 38.9 & 25.7 & 36.6 & 42.9 & 35.2 & 44.8 & 89.1 \\
\hline Real Hourly Wage (in logs) & 1.29 & 1.01 & 1.63 & 0.95 & 1.02 & 1.02 & 0.79 & 0.99 \\
\hline Minimum Wage Earners (\%) & 5.5 & 10.4 & 5.2 & 10.1 & 9.3 & 10.1 & 11.2 & 47.7 \\
\hline Number of Observations & $2,071,710$ & 103,598 & 5,102 & 45,215 & 21,502 & 17,296 & 1,377 & 13,106 \\
\hline
\end{tabular}

Notes: (i) Real hourly wages in log EURO;

(ii) EU14: Austria, Belgium, Denmark, Finland, France, Germany, Greece, Italy, Ireland, Luxemburg, The Netherlands, Spain, Sweden and United Kingdom; Former USSR: Russia, 16 kraine, Moldova and other former USSR nations;

Africa \& E.Timor: Angola, Cape Verde, Guinea-Bissau, Mozambique, São Tomé \& Príncipe, and East-Timor. 
Table A.2: Sample means 2003-04 - Women

\begin{tabular}{|c|c|c|c|c|c|c|c|c|}
\hline \multirow[b]{2}{*}{ Variables } & \multirow[b]{2}{*}{ Natives } & \multirow[b]{2}{*}{ Immig. } & \multicolumn{6}{|c|}{ Groups of Immigrants } \\
\hline & & & EU14 & $\begin{array}{c}\text { Former } \\
\text { USSR }\end{array}$ & $\begin{array}{l}\text { Africa \& } \\
\text { E.Timor }\end{array}$ & Brazil & China & Others \\
\hline Age (in years) & 36.5 & 34.7 & 34.2 & 35.9 & 35.6 & 32.1 & 33.4 & 32.9 \\
\hline \multicolumn{9}{|l|}{ Years since migration (\%) } \\
\hline$\leq 5$ & & 79.2 & 64.5 & 85.4 & 68.7 & 93.4 & 90.4 & 85.1 \\
\hline$>5$ and $\leq 10$ & & 10.6 & 18.3 & 4.9 & 17.4 & 3.4 & 7.5 & 8.3 \\
\hline$>10$ & & 10.2 & 17.2 & 9.7 & 13.9 & 3.1 & 2.2 & 6.6 \\
\hline Tenure (in years) & 7.1 & 2.3 & 3.5 & 2.4 & 2.4 & 1.4 & 1.8 & 2.2 \\
\hline \multicolumn{9}{|l|}{ Education Levels (\%) } \\
\hline Less than 6 years & 26.4 & 31.5 & 9.7 & 27.9 & 49.2 & 17.1 & 47.7 & 22.3 \\
\hline 6 years completed & 21.7 & 13.8 & 8.1 & 14.5 & 13.6 & 16.3 & 11.7 & 13.0 \\
\hline 9 years completed & 19.1 & 18.6 & 19.6 & 19.7 & 16.4 & 22.2 & 13.8 & 19.1 \\
\hline 12 years completed & 21.4 & 16.1 & 20.0 & 18.5 & 12.7 & 30.6 & 3.8 & 26.2 \\
\hline College education & 11.1 & 4.9 & 8.0 & 6.7 & 3.5 & 6.6 & 1.8 & 10.4 \\
\hline Non-defined & 0.2 & 8.0 & 6.8 & 12.6 & 4.5 & 7.3 & 21.3 & 9.0 \\
\hline \multicolumn{9}{|l|}{ Qualification Levels (\%) } \\
\hline Highly Professional & 4.4 & 2.3 & 10.3 & 1.1 & 1.4 & 1.7 & 2.3 & 3.0 \\
\hline Professional & 3.9 & 2.4 & 15.0 & 0.9 & 1.0 & 1.6 & 1.8 & 2.5 \\
\hline Supervisors & 2.4 & 0.9 & 4.2 & 0.5 & 0.5 & 0.8 & 0.4 & 1.1 \\
\hline Highly Skilled and Skilled & 45.0 & 26.2 & 43.1 & 22.5 & 17.4 & 35.6 & 56.4 & 31.2 \\
\hline Semi-skilled and Unskilled & 36.5 & 56.3 & 17.5 & 61.6 & 70.7 & 43.9 & 28.5 & 50.2 \\
\hline Apprentices & 5.6 & 8.1 & 5.0 & 10.5 & 4.8 & 11.6 & 10.3 & 9.3 \\
\hline Non-defined & 2.2 & 3.8 & 2.8 & 3.4 & 4.2 & 4.8 & 0.4 & 2.7 \\
\hline \multicolumn{9}{|l|}{ Industry (\%) } \\
\hline Agriculture \& fishing & 1.3 & 2.2 & 1.6 & 4.8 & 0.6 & 0.9 & 0.3 & 5.5 \\
\hline Mining \& quarrying & 0.1 & 0.1 & 0.1 & 0.1 & 0.0 & 0.0 & 0.0 & 0.2 \\
\hline Manufacturing & 31.6 & 13.9 & 17.1 & 27.7 & 5.6 & 9.5 & 0.5 & 13.8 \\
\hline Electricity, gas \& water & 0.2 & 0.1 & 0.0 & 0.2 & 0.1 & 0.0 & 0.0 & 0.2 \\
\hline Construction & 2.3 & 1.9 & 3.0 & 2.5 & 1.1 & 1.8 & 0.3 & 2.4 \\
\hline Wholesale, retail trade \& hotels & 29.6 & 39.0 & 30.8 & 38.5 & 29.4 & 54.9 & 97.3 & 44.1 \\
\hline Transport, storage \& communications & 3.1 & 1.4 & 5.1 & 0.6 & 1.3 & 1.1 & 0.1 & 1.6 \\
\hline Banking, insurance \& services to firms & 13.5 & 28.5 & 13.0 & 16.5 & 50.4 & 18.5 & 0.3 & 16.3 \\
\hline Community, social \& personal services & 18.2 & 13.0 & 29.2 & 9.1 & 11.6 & 13.3 & 1.2 & 16.0 \\
\hline Plant Size (in logs) & 3.49 & 3.78 & 3.76 & 3.43 & 4.59 & 3.20 & 1.45 & 3.34 \\
\hline Concentration of Immigrants (\%) & 2.7 & 35.0 & 28.7 & 38.9 & 33.1 & 33.9 & 89.6 & 30.2 \\
\hline Real Hourly Wage (in logs) & 1.13 & 0.98 & 1.47 & 0.89 & 0.94 & 0.94 & 0.77 & 1.13 \\
\hline Minimum Wage Earners (\%) & 12.9 & 24.6 & 8.0 & 22.0 & 32.7 & 20.0 & 57.9 & 19.5 \\
\hline Number of Observations & $1,583,334$ & 52,626 & 4,558 & 14,354 & 18,891 & 10,191 & 738 & 3,894 \\
\hline
\end{tabular}

Notes: (i) Real hourly wages in log EURO;

(ii) EU14: Austria, Belgium, Denmark, Finland, France, Germany, Greece, Italy, Ireland, Luxemburg, The Netherlands, Spain, Sweden and United Kingdom; Former USSR: Russia, Ukraine, Moldova and other former USSR nations;

Africa \& E.Timor: Angola, Cape Verde, Guinea-Bissau, Mozambique, São Tomé \& Príncipe, and East-Timor. 


\title{
APPENDIX B - Variables Definition
}

\author{
$\mathrm{IMIG}=1$ if immigrant; \\ AGE: age (in years); \\ AGESQ: age squared (in years); \\ YSM: number of years since migration; \\ YSMSQ: YSM squared; \\ EDUCATION LEVELS \\ - COLLEGE EDUCATION $=1$; \\ . 12 YEARS COMPLETED =1; \\ . 9 YEARS COMPLETED $=1$; \\ - 6 YEARS COMPLETED $=1$; \\ - LESS THAN 6 YEARS =1 (the omitted category); \\ - NON-DEFINED $=1$ (residual category).
}

TENURE: number of years with the current employer;

TENURESQ: tenure squared;

QUALIFICATION LEVELS

- HIGHLY PROFESSIONAL $=1$;

- PROFESSIONAL $=1$;

- SUPERVISORS =1;

- HIGHLY SKILLED AND SKILLED =1;

- SEMI-SKILLED AND UNSKILLED =1;

- APPRENTICES =1 (the omitted category);

- NON-DEFINED $=1$ (residual category).

LPIMIGE: proportion of non-natives workers in the establishment (lagged by one year);

LSIZE: number of employees in the establishment (in logs).

REGIONAL DUMMIES: are defined at the level of NUTS III;

INDUSTRY DUMMIES: are defined at the one-digit level according to the Portuguese Classification of Economic Activities (CAE);

REAL HOURLY WAGE: the ratio between the real monthly base wage and the total number of hours usually worked (in log EURO; base=2002). 


\section{APPENDIX C - Full OLS and FE Results}

Table C.1: Wage regression - Male sample, 2003-04 Dependent variable: $\log$ of real hourly wage

\begin{tabular}{|c|c|c|c|c|}
\hline & \multicolumn{3}{|c|}{ OLS } & \multirow{2}{*}{$\begin{array}{c}\text { Establishment } \\
\text { FE }\end{array}$} \\
\hline & Specification 1 & Specification 2 & Specification 3 & \\
\hline \multirow[t]{2}{*}{ IMIG } & $-0.31671^{*}$ & $-0.24523^{*}$ & $-0.11094^{*}$ & $-0.07837^{*}$ \\
\hline & $(0.00194)$ & $(0.00203)$ & $(0.00173)$ & $(0.00130)$ \\
\hline \multirow[t]{2}{*}{ YSM } & $0.02411^{*}$ & $0.02336^{*}$ & $0.01204^{*}$ & $0.00572^{*}$ \\
\hline & $(0.00078)$ & $(0.00075)$ & $(0.00066)$ & $(0.00040)$ \\
\hline \multirow[t]{2}{*}{ YSMSQ } & $-0.00047^{*}$ & $-0.00045^{*}$ & $-0.00029^{*}$ & $-0.00016^{*}$ \\
\hline & $(0.00003)$ & $(0.00003)$ & $(0.00003)$ & $(0.00002)$ \\
\hline \multirow[t]{2}{*}{ LPIMIGE } & & $-0.20541^{*}$ & $-0.16965^{*}$ & -0.00370 \\
\hline & & $(0.00253)$ & $(0.00221)$ & $(0.00424)$ \\
\hline \multirow[t]{2}{*}{ AGE } & $0.04953^{*}$ & $0.04715^{*}$ & $0.02604^{*}$ & $0.02143^{*}$ \\
\hline & $(0.00019)$ & $(0.00019)$ & $(0.00018)$ & $(0.00012)$ \\
\hline \multirow[t]{2}{*}{ AGESQ } & $-0.00044^{*}$ & $-0.00043^{*}$ & $-0.00026^{*}$ & $-0.00020^{*}$ \\
\hline & $(0.00000)$ & $(0.00000)$ & $(0.00003)$ & $(0.00000)$ \\
\hline \multicolumn{5}{|l|}{ EDUCATION LEVELS } \\
\hline \multirow[t]{2}{*}{6 years completed } & $0.12681^{*}$ & $0.11345^{*}$ & $0.08335^{*}$ & $0.06271^{*}$ \\
\hline & $(0.00081)$ & $(0.00078)$ & $(0.00069)$ & $(0.00053)$ \\
\hline \multirow[t]{2}{*}{9 years completed } & $0.25562^{*}$ & $0.22221^{*}$ & $0.16659^{*}$ & $0.10801^{*}$ \\
\hline & $(0.00098)$ & $(0.00095)$ & $(0.00083)$ & $(0.00059)$ \\
\hline \multirow[t]{2}{*}{12 years completed } & $0.44956^{*}$ & $0.40052^{*}$ & $0.29307^{*}$ & $0.16303^{*}$ \\
\hline & $(0.00117)$ & $(0.00116)$ & $(0.00104)$ & $(0.00067)$ \\
\hline \multirow[t]{2}{*}{ College education } & $0.96921^{*}$ & $0.90261^{*}$ & $0.58580^{*}$ & $0.37645^{*}$ \\
\hline & $(0.00166)$ & $(0.00164)$ & $(0.00185)$ & $(0.00098)$ \\
\hline \multirow[t]{2}{*}{ Non-defined } & $0.10650^{*}$ & $0.13155^{*}$ & $0.10543^{*}$ & $0.08010^{*}$ \\
\hline & $(0.00315)$ & $(0.00296)$ & $(0.00254)$ & $(0.00241)$ \\
\hline \multirow[t]{2}{*}{ LSIZE } & & $0.04677^{*}$ & $0.04411^{*}$ & $0.00307^{* *}$ \\
\hline & & $(0.00020)$ & $(0.00018)$ & $(0.00126)$ \\
\hline \multirow[t]{2}{*}{ TENURE } & & & $0.01724^{*}$ & $0.01273^{*}$ \\
\hline & & & $(0.00010)$ & $(0.00007)$ \\
\hline \multirow[t]{2}{*}{ TENURESQ } & & & $-0.00028^{*}$ & $-0.00021^{*}$ \\
\hline & & & $(0.00000)$ & $(0.00000)$ \\
\hline \multicolumn{5}{|l|}{ QUALIFICATION LEVELS } \\
\hline Highly professional & & & $0.60047^{*}$ & $\begin{array}{c}0.67406^{*} \\
000136)\end{array}$ \\
\hline \multirow[t]{2}{*}{ Professional } & & & $0.56182^{*}$ & $0.54914^{*}$ \\
\hline & & & $(0.00207)$ & $(0.00134)$ \\
\hline \multirow[t]{2}{*}{ Supervisors } & & & $0.40891^{*}$ & $0.42548^{*}$ \\
\hline & & & $(0.00167)$ & $(0.00124)$ \\
\hline \multirow[t]{2}{*}{ Highly-skilled and skilled } & & & $0.18056^{*}$ & $0.18468^{*}$ \\
\hline & & & $(0.00096)$ & $(0.00100)$ \\
\hline \multirow[t]{2}{*}{ Semi-skilled and unskilled } & & & $0.00789^{*}$ & $0.02010^{*}$ \\
\hline & & & $(0.00096)$ & $(0.00104)$ \\
\hline Non-defined & & & $0.08827^{*}$ & $0.15466^{*}$ \\
\hline & & & $(0.00178)$ & $(0.00151)$ \\
\hline CONSTANT & $-0.00705^{* * *}$ & $-0.10006^{*}$ & $0.20104^{*}$ & $0.44149^{*}$ \\
\hline & $(0.00366)$ & $(0.00366)$ & $(0.00326)$ & $(0.01181)$ \\
\hline $\mathrm{N}$ & 2175308 & 2175308 & 2175308 & 2175308 \\
\hline R-sq & 0.4312 & 0.4762 & 0.5829 & 0.4959 \\
\hline
\end{tabular}

Notes: (i) specification 1 includes a set of regional and time dummies;

(ii) specifications 2 and 3 include a set of regional, industry and time dummies;

(iii) robust cluster standard errors in parentheses for the pooled OLS model;

(iv) $*, * *, * * *$ denotes significant at $1 \%, 5 \%$ and $119 \%$, respectively. 
Table C.2: Wage regression - Female sample, 2003-04

Dependent variable: log of real hourly wage

\begin{tabular}{|c|c|c|c|c|}
\hline & \multicolumn{3}{|c|}{ OLS } & \multirow{2}{*}{$\begin{array}{c}\text { Establishment } \\
\text { FE }\end{array}$} \\
\hline & Specification 1 & Specification 2 & Specification 3 & \\
\hline \multirow[t]{2}{*}{ IMIG } & $-0.19833^{*}$ & $-0.14613^{*}$ & $-0.06200^{*}$ & $-0.03255^{*}$ \\
\hline & $(0.00252)$ & $(0.00261)$ & $(0.00216)$ & $(0.00156)$ \\
\hline \multirow[t]{2}{*}{ YSM } & $0.01510^{*}$ & $0.01341^{*}$ & $0.00488^{*}$ & $0.00344^{*}$ \\
\hline & $(0.00093)$ & $(0.00063)$ & $(0.00076)$ & $(0.00045)$ \\
\hline \multirow[t]{2}{*}{ YSMSQ } & $-0.00047^{*}$ & -0.00007 & 0.00004 & -0.00003 \\
\hline & $(0.00003)$ & $(0.00005)$ & $(0.00004)$ & $(0.00002)$ \\
\hline \multirow[t]{2}{*}{ LPIMIGE } & & $-0.25157^{*}$ & $-0.17160^{*}$ & $-0.02344^{*}$ \\
\hline & & $(0.00339)$ & $(0.00290)$ & $(0.00493)$ \\
\hline \multirow[t]{2}{*}{ AGE } & $0.03800^{*}$ & $0.03516^{*}$ & $0.01974^{*}$ & $0.01277^{*}$ \\
\hline & $(0.00021)$ & $(0.00020)$ & $(0.00018)$ & $(0.00013)$ \\
\hline \multirow[t]{2}{*}{ AGESQ } & $-0.00033^{*}$ & $-0.00030^{*}$ & $-0.00018^{*}$ & $-0.00011^{*}$ \\
\hline & $(0.00000)$ & $(0.00000)$ & $(0.00000)$ & $(0.00000)$ \\
\hline \multicolumn{5}{|l|}{ EDUCATION LEVELS } \\
\hline \multirow[t]{2}{*}{6 years completed } & $0.12028^{*}$ & $0.11958^{*}$ & $0.07866^{*}$ & $0.05694^{*}$ \\
\hline & $(0.00080)$ & $(0.00077)$ & $(0.00070)$ & $(0.00058)$ \\
\hline \multirow[t]{2}{*}{9 years completed } & $0.27121^{*}$ & $0.26409^{*}$ & $0.18747^{*}$ & $0.12598^{*}$ \\
\hline & $(0.00104)$ & $(0.00101)$ & $(0.00086)$ & $(0.00066)$ \\
\hline \multirow[t]{2}{*}{12 years completed } & $0.45725^{*}$ & $0.43512^{*}$ & $0.31982^{*}$ & $0.19305^{*}$ \\
\hline & $(0.00111)$ & $(0.00111)$ & $(0.00098)$ & $(0.00072)$ \\
\hline \multirow[t]{2}{*}{ College education } & $1.03339^{*}$ & $0.98787^{*}$ & $0.68234^{*}$ & $0.43607^{*}$ \\
\hline & $(0.00159)$ & $(0.00158)$ & $(0.00171)$ & $(0.00097)$ \\
\hline \multirow[t]{2}{*}{ Non-defined } & $0.18430^{*}$ & $0.21807^{*}$ & $0.17010^{*}$ & $0.11677^{*}$ \\
\hline & $(0.00474)$ & $(0.00470)$ & $(0.00404)$ & $(0.00316)$ \\
\hline LSIZE & & $0.03837^{*}$ & $0.03640^{*}$ & $-0.00822^{*}$ \\
\hline & & $(0.00019)$ & $(0.00018)$ & $(0.00133)$ \\
\hline TENURE & & & $0.01640^{*}$ & $0.01390^{*}$ \\
\hline & & & $(0.00011)$ & $(0.00008)$ \\
\hline TENURESQ & & & $-0.00026^{*}$ & $-0.00025^{*}$ \\
\hline & & & $(0.00000)$ & $(0.00000)$ \\
\hline \multicolumn{5}{|l|}{ QUALIFICATION LEVELS } \\
\hline \multirow[t]{2}{*}{ Highly professional } & & & $0.54327^{*}$ & $0.57441^{*}$ \\
\hline & & & $(0.00240)$ & $(0.00140)$ \\
\hline \multirow[t]{2}{*}{ Professional } & & & $0.49957^{*}$ & $0.49638^{*}$ \\
\hline & & & $(0.00235)$ & $(0.00139)$ \\
\hline \multirow[t]{2}{*}{ Supervisors } & & & $0.35803^{*}$ & $0.37972^{*}$ \\
\hline & & & $(0.00232)$ & $(0.00147)$ \\
\hline \multirow[t]{2}{*}{ Highly skilled and skilled } & & & $0.14004^{*}$ & $0.12870^{*}$ \\
\hline & & & $(0.00090)$ & $(0.00097)$ \\
\hline Semi-skilled and unskilled & & & $0.00234^{*}$ & $-0.01930^{*}$ \\
\hline & & & $(0.00088)$ & $(0.00099)$ \\
\hline Non-defined & & & 0.00008 & $0.06609^{*}$ \\
\hline & & & $(0.00217)$ & $(0.00169)$ \\
\hline CONSTANT & $0.03958^{*}$ & $-0.07646^{*}$ & $0.16889^{*}$ & $0.55714^{*}$ \\
\hline & $(0.00394)$ & $(0.00399)$ & $(0.00355)$ & $(0.01140)$ \\
\hline $\mathrm{N}$ & 1635960 & 1635960 & 1635960 & 1635960 \\
\hline R-sq & 0.5131 & 0.5464 & 0.6357 & 0.4945 \\
\hline
\end{tabular}

Notes: (i) specification 1 includes a set of regional and time dummies;

(ii) specifications 2 and 3 include a set of regional, industry and time dummies;

(iii) robust cluster standard errors in parentheses for the pooled OLS model;

(iv) $*, * *, * * *$ denotes significant at $1 \%, 5 \%$ and $10 \%$, respectively. 


\section{APPENDIX D - Full OLS Results}

Table D: Pooled OLS wage regressions (specification 3), 2003-04 Dependent variable: $\log$ of real hourly wage

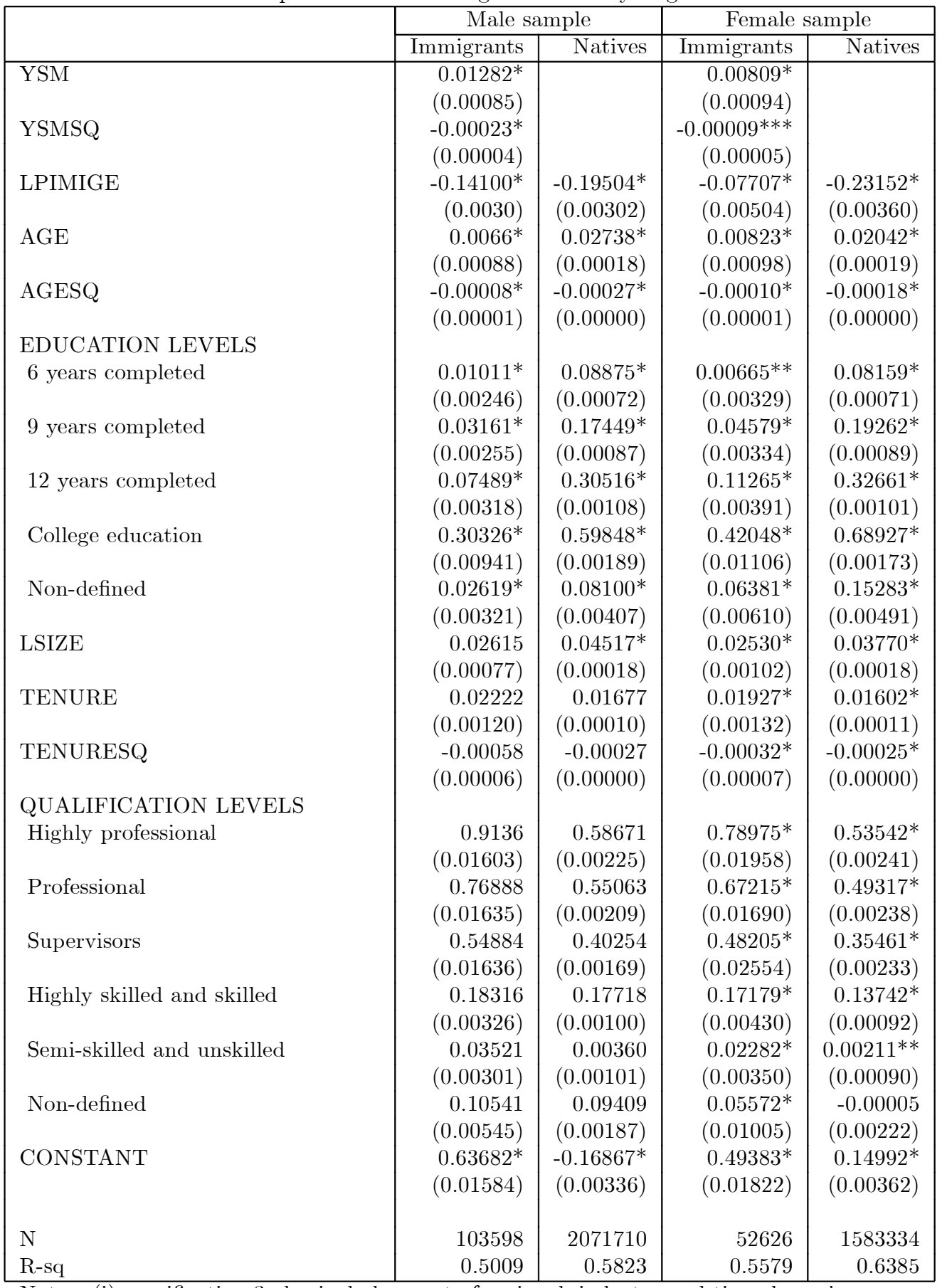

Notes: (i) specification 3 also includes a set of regional, industry and time dummies;

(ii) robust cluster standard errors in parentheses;

(iii) $*, * *, * * *$ denotes significant at $1 \%, 5 \%$ and $10 \%$, respectively. 


\section{References}

BorJas GJ (1999) Heaven's Door: Immigration Policy and the American Economy, Princeton University Press, Princeton.

Borjas GJ (2000) Ethnic Enclaves and Assimilation. Swedish Economic Policy Review, 7(2): 89-122.

Carrington WJ, Lima, PJF (1996) The Impact of 1970s Repatriates from Africa on the Portuguese Labor Market. Industrial and Labor Relations Review, 49(2): 330-347.

CHIswick BR (1978) The Effect of Americanization on the Earnings of Foreignborn Men Journal of Political Economy, 86(5): 897-921.

Chiswick BR (1979) The Economic Progress of Immigrants: Some Apparently Universal Patterns. In: Fellner W (ed) Contemporary Economic Problems. American Enterprise Institute, Washington D.C., 357-399.

Chiswick BR, Miller, PW (2002) Immigrant Earnings: Language Skills, Linguistic Concentrations and the Business Cycle. Journal of Population Economics, 15(1): 31-57.

Cohen S, Eckstein, Z (2002) Labor Mobility of Immigrants: Training, Experience, Language and Opportunities. International Economic Review, 49(3): 837-872.

Eckstein Z, Weiss, Y (2004) On the Wage Growth of Immigrants: Israel, 1990-2000. Journal of the European Economic Association, 2(4): 665-695.

Friedberg RM (2000) You Can't Take It with You? Immigrant Assimilation and the Portability of Human Capital. Journal of Labor Economics, 18(2): 221-251.

Green DA (1999) Immigrant Occupational Attainment and Mobility over Time. Journal of Labor Economics, 17(1): 49-79.

Groshen E (1990) The Structure of the Female/Male Wage Differential: Is It Who You Are, What You Do, or Where You Work?. Journal of Human Resources, 26(3): 457-472.

Jasso G (2008) A New Unified Theory of Sociobehavioural Forces. European Sociological Review, 24(4): 411-434.

Koencker R (2005) Quantile Regression. Cambridge University Press, Cambridge.

Mincer J (1974) Schooling, Experience and Earnings. Columbia University Press, New York.

Pereira SC (2003) The Impact of Minimum Wage on Youth Employment in Portugal. European Economic Review, 47(2): 229-244. 
Portugal P, Cardoso AR (2006) Disentangling the Minimum Wage Puzzle: An Analysis of Worker Accessions and Separations from a Longitudinal Matched Employer-Employed Data Set. Journal of the European Economic Association, 4(5): 988-1013.

SOPEMI (2002) Trends in International Migration. OECD Publications Service, Paris.

Venturini A (2004) Postwar Migration in Southern Europe, 1950-2000. An Economic Analysis. Cambridge University Press, Cambridge.

Weiss Y, Sauer RM, Gotlibovski M (2003) Immigration, Search and Loss of Skill. Journal of Labor Economics, 21(3): 221-251. 